Pak. j. sci. ind. res. Ser. B: biol. sci. 2019 62B(3) 133-138

\title{
Impact of Green Manuring and Crop Residues Incorporation along with Gypsum on Rehabilitation of Saline Sodic Soil and Yield of Direct Seeded and Transplanted Rice
}

\author{
Imdad Ali Mahmood ${ }^{a *}$, Muhammad Arshad Ullaha, Muhammad Jamil ${ }^{\mathrm{b}}$, Badar-uz-Zamana, \\ Muhammad Suhaib ${ }^{a}$ and Syed Ishtiaq Haider ${ }^{a}$ \\ ${ }^{a}$ Land Resources Research Institute, National Agricultural Research Centre, Park Road, \\ Islamabad-45500, Pakistan \\ ${ }^{\mathrm{b}}$ Soil Salinity Research Institute, Pindi Bhattian, Pakistan
}

(received May 29, 2017; revised January 23, 2018; accepted February 19, 2018)

\begin{abstract}
A two years field study on rice was conducted to see the efficacy of gypsum to improve soil productivity with green manuring $(\mathrm{GM})$ and crop residue $(\mathrm{CR})$ incorporation and its impact on paddy yield of direct seeded rice and transplanted rice grown under saline-sodic soil having $\mathrm{pH}=8.36 ; \mathrm{ECe}=6.78 \mathrm{dS} / \mathrm{m}$; $\mathrm{SAR}=26.55\left(\mathrm{mmol}_{\mathrm{c}} / \mathrm{L}\right)^{1 / 2}$ at the Farm of Soil Salinity Research Institute, Pindi Bhattian during 2014 and 2015. The experiment was planned employing split plot design with three replications. Planting methods (GM and CR incorporation) were kept in main plots and gypsum @ 0, 50, 75 and 100\% GR was applied in sub plots. Data on productive tillers, plant height, straw and paddy yields were collected at the time of harvest. The paddy yield was increased with the increasing GR (gypsum requirement) applied without GM or CR incorporation. The maximum yield was attained at 100\% GR level in both DSR (direct seeded rice; $2.27 \mathrm{t} / \mathrm{ha}$ ) and TPR (transplanted rice; $1.94 \mathrm{t} / \mathrm{ha}$ ) followed by $75 \%$ GR (2.16 and $1.92 \mathrm{t} / \mathrm{ha}$, respectively) and $50 \%$ GR (2.13 and 1.90 t/ha, respectively). Overall DSR out yielded compared to TPR in all treatments even at control ( $0 \%$ GR). Paddy yield was further improved with the incorporation of GM and CR to almost all GR levels and was statistically at par for both DSR and TPR. It was quite less under transplanted rice even with $100 \%$ GR application. Soil ECe and SAR were decreased significantly where GM and CR were incorporated along with gypsum application. Soil organic matter (SOM) intensity was also improved due to GM and CR incorporation particularly during the second year of crop harvest.
\end{abstract}

Keywords: saline-sodic soil, direct seeded rice, transplanted rice, gypsum efficacy, green mannuring, soil rehabilitation

\section{Introduction}

In culturable land of the country, 6.38 million hectares (mha) are salt-affected to varying degrees out of which 2.67 mha are in the Punjab having marginal to high salinity (GOP, 2016). Generally, crop growth on these soils is limited due to toxicity of specific ions, availability of water and nutrients. Green manuring (GM) and crop residues (CR) are good sources of plant nutrients, primary source of organic material added to the soil which is very important for improving soil physical condition and the stability of agricultural ecosystem. About $25 \%$ of $\mathrm{N}$ and $\mathrm{P}, 50 \%$ of the $\mathrm{S}$, and $75 \%$ of $\mathrm{K}$ uptake by cereal crops are retained in crop residues, making them valuable nutrient sources. Since large portion of plant nutrients taken up by plants remains in residues, much of this can be recycled for subsequent crop growth after its decomposition (Byous et al., 2004).

*Author for correspondence; E-mail: imdadlrri@gmail.com
In many studies, recycling of crop residues is reported to increase the organic carbon and nutrient contents; decreased soil bulk density and increased soil aeration and water holding capacity as well as improved fertility status of the soil (Mahmood and Ali, 2015; Mahmood et al., 2013; Eagle et al., 2000; ). The major constraint in the rice-wheat cropping system is the available short time between rice harvesting and plantation of wheat and any delay in planting adversely affected the crop growth and yield. With improved accessibility to farm machinery, about 60 to $80 \%$ of rice and wheat crops are being harvested with combined harvester. The combined harvester leaves behind a large amount of loose straw in the field, the disposal or utilization of which, in the short time is difficult compelling farmers to burn the residue to get rid of it (Mahmood and Ali, 2015; Ali et al., 2012; Danga and Wakindiki, 2009). The leftover crop residues hinder farm operations by blocking/choking of tillage machinery and thus delays 
seed bed preparation for the succeeding crop. Preparation of field also involved removal or utilization of rice straw left in the fields that is expensive and labour inhibitive encouraging its burning. Situation after rice harvesting is also the same. Now the practice of CR burning has been banned in Pakistan due to its after affects like smog and other environmental issues. Gypsum is the most extensively used amendment for the reclamation of saline-sodic soils because of its low cost, general availability, and rich supply of $\mathrm{Ca}^{2+}$ followed by leaching can ameliorate saline-sodic soils (Murtaza et al., 2009; Ghafoor et al., 2008; Tuna et al., 2007).

Keeping all these factors in mind, present study was planned to investigate the effect of GM and CR incorporation alongwith gypsum application on rehabilitation saline-sodic soil and its impact on growth and yield of directly sowing and transplanted rice.

\section{Materials and Methods}

A two years field study was conducted to investigate the effect of gypsum application with and without GM (Jantar) and CR incorporation ( $2 \mathrm{t} / \mathrm{ha}$ ) on direct seeded rice (DSR) and transplanted Rice (TPR) in a permanent layout under saline-sodic field (sandy loam) having $\mathrm{pH}=8.36 ; \mathrm{ECe}=6.78 \mathrm{dS} / \mathrm{m} ; \mathrm{SAR}=26.55\left(\mathrm{mmol}_{\mathrm{c}} / \mathrm{L}\right)^{1 / 2}$, $\mathrm{CaCO}_{3}=3.54 \%$ and organic matter $=0.33 \%$ under ricewheat cropping system at Soil Salinity Research Institute (SSRI) Farm, Pindi Bhattian, Pakistan during 2014 and 2015. The experiment was designed employing split plot with three replications. The main plots (Factor A) were occupied by planting methods i.e., with and without GM and CR incorporation and the sub plots (Factor B) consisted of gypsum application. The treatments for each sub plot were:

$\mathrm{T} 1=$ Control (no gypsum application); $\mathrm{T} 2=50 \% \mathrm{GR}$ (6 t/ha); T3 = $75 \%$ GR (9 t/ha); T4 = $100 \%$ GR (12 t/ha).

Recommended basal dose of N@100 kg/ha as urea was applied in two splits (half at sowing time and remaining half at tillering stage). The P and K@80 and $50 \mathrm{~kg} / \mathrm{ha}$ as SSP and SOP, respectively were applied to all plots at the time of sowing. Soaked seed (for 24 h) of rice cv. Supper Basmati @ 40 kg/ha was broadcast uniformly. The same inputs were applied to transplanted rice. Effective weedicide was used to control weeds and the crops were grown to maturity. All agronomic requirements and plant protection measures were met throughout the growth periods whenever required. Presowing soil samples $(0-15 \mathrm{~cm}$ depth) were collected for the analysis of general soil characteristics (Table 1) according to the methods suggested by Ryan et al. (2001). Plant samples from both (DSR and TPR) were collected at maturity for the determination of ionic concentration $\left(\mathrm{Na}^{+}, \mathrm{Mg}^{2+}, \mathrm{Ca}^{2+}\right)$ in their tissues. Dried and ground samples were digested in perchloric-nitric acid $(2: 11 \mathrm{~N})$ mixture (Rhoades, 1982) to estimate $\mathrm{P}$, $\mathrm{K}, \mathrm{Na}^{+}, \mathrm{Ca}^{2+}$ and $\mathrm{Mg}^{2+}$ by spectronic- 20 and atomic absorption spectrophotometer. At maturity, the crops were harvested and agronomic data on fertile tillers, plant height, panicle length, grains panicle, 1000-grain weight, paddy and straw yields were recorded. The data, thus collected, were subjected to statistical analysis using software package MSTAT-C and treatment means were compared using least significant difference (LSD) at 5\% probability level (Gomez and Gomez, 1984).

\section{Results and Discussion}

Productive tillers. The data in Table 2 reveals that the treatments amended with GM and CR had significant effect on the number of productive tillers in both DSR and TPR with increasing GR level up to $100 \%$. Under control conditions (without GM and CR), the maximum productive tillers/plant of DSR (12.67) and (11.00) of TPR were recorded with $100 \%$ GR. The increase in number of productive tillers was further augmented by incorporating GM and CR under both DSR and TPR

Table 1. Physico-chemical analysis of the soil $(0-15$ $\mathrm{cm}$ ) before crop sowing

\begin{tabular}{lll}
\hline \hline Parameters & Unit & Values \\
\hline $\mathrm{pH}$ & - & 8.36 \\
$\mathrm{ECe}$ & $(\mathrm{dS} / \mathrm{m})$ & 6.78 \\
$\mathrm{SAR}$ & - & 26.55 \\
$\mathrm{OM}$ (Walkley Black) & $(\%)$ & 0.33 \\
Total N & $(\%)$ & 0.029 \\
$\mathrm{NO}_{3}-\mathrm{N}(\mathrm{AB}-\mathrm{DTPA})$ & $(\mathrm{ppm})$ & 1.99 \\
Total P (Olsen) & $(\mathrm{ppm})$ & 5.43 \\
Extractable P (AB-DTPA) & $(\mathrm{mg} / \mathrm{kg})$ & 2.28 \\
Extractable K (AB-DTPA) & $(\mathrm{mg} / \mathrm{kg})$ & 44.35 \\
$\mathrm{Na}_{\mathrm{Ca}+\mathrm{Mg}}$ & $(\mathrm{ppm})$ & 794 \\
$\mathrm{CaCO}$ & $(\mathrm{me} / \mathrm{L})$ & 3.38 \\
$\mathrm{HCO}_{3}$ & $(\%)$ & 3.54 \\
$\mathrm{Sand}$ & $(\mathrm{me} / \mathrm{L})$ & 2.98 \\
Silt & $(\%)$ & 60 \\
$\mathrm{Clay}_{\text {Textural Class }}$ & $(\%)$ & 30 \\
\hline \hline
\end{tabular}


Table 2. Impact of green manuring and crop residue incorporation along with gypsum on growth and paddy yield of direct seeded and transplanted rice grown under saline-sodic soil. (Average of three replications)

\begin{tabular}{|c|c|c|c|c|c|c|c|c|}
\hline \multicolumn{3}{|c|}{ Direct seeded rice } & \multicolumn{6}{|c|}{ Transplanted rice } \\
\hline Treatments & Control & GM & $\mathrm{CR}$ & Mean & Control & GM & CR & Mean \\
\hline \multicolumn{9}{|c|}{ Productive tillers/Plant } \\
\hline $0 \%$ GR & $7.33 \mathrm{e}$ & $11.67 \mathrm{c}$ & $11.33 \mathrm{c}$ & $10.11 \mathrm{C}$ & $6.67 \mathrm{~d}$ & $9.67 \mathrm{c}$ & $8.33 \mathrm{~cd}$ & $8.22 \mathrm{C}$ \\
\hline $50 \%$ GR & $9.67 \mathrm{~d}$ & $15.33 \mathrm{a}$ & $14.67 \mathrm{ab}$ & $13.22 \mathrm{AB}$ & $8.00 \mathrm{~d}$ & $12.67 \mathrm{a}$ & $11.67 \mathrm{ab}$ & $10.78 \mathrm{AB}$ \\
\hline $75 \%$ GR & $10.33 \mathrm{~cd}$ & $16.33 \mathrm{a}$ & $15.33 \mathrm{a}$ & $14.00 \mathrm{~A}$ & $10.33 \mathrm{~b}$ & $13.00 \mathrm{a}$ & $12.00 \mathrm{a}$ & $12.00 \mathrm{~A}$ \\
\hline $100 \%$ GR & $12.67 \mathrm{c}$ & $16.67 \mathrm{a}$ & $16.00 \mathrm{a}$ & $15.11 \mathrm{~A}$ & $11.00 \mathrm{ab}$ & $13.33 \mathrm{a}$ & $12.67 \mathrm{a}$ & $12.33 \mathrm{~A}$ \\
\hline Means & $10.00 \mathrm{~B}$ & $15.00 \mathrm{~A}$ & $14.33 \mathrm{~A}$ & & $9.00 \mathrm{~B}$ & $12.17 \mathrm{~A}$ & $11.17 \mathrm{~A}$ & \\
\hline \multicolumn{9}{|c|}{ Plant Height $(\mathrm{cm})$} \\
\hline $0 \% \mathrm{GR}$ & & $93.67 \mathrm{~d}$ & $92.33 \mathrm{~d}$ & $91.89 \mathrm{~d}$ & $88.33 \mathrm{~d}$ & $92.33 \mathrm{~b}$ & $91.00 \mathrm{bc}$ & $90.55 \mathrm{D}$ \\
\hline $50 \% \mathrm{GR}$ & $90.00 \mathrm{~d}$ & $100.33 \mathrm{a}$ & $98.67 \mathrm{~b}$ & $96.67 \mathrm{bc}$ & $91.00 \mathrm{bc}$ & $96.67 \mathrm{ab}$ & $95.33 \mathrm{~b}$ & $94.33 \mathrm{C}$ \\
\hline $75 \%$ GR & $93.33 \mathrm{c}$ & $101.67 \mathrm{a}$ & $99.33 \mathrm{ab}$ & $98.00 \mathrm{~b}$ & $94.33 \mathrm{~b}$ & $98.67 \mathrm{a}$ & $97.33 \mathrm{a}$ & $99.11 \mathrm{~A}$ \\
\hline $100 \%$ GR & $93.67 \mathrm{c}$ & $102.33 \mathrm{a}$ & $100.66 \mathrm{a}$ & $99.33 \mathrm{ab}$ & $95.67 \mathrm{~b}$ & $98.33 \mathrm{a}$ & $96.67 \mathrm{ab}$ & $96.89 \mathrm{~B}$ \\
\hline Means & $91.00 \mathrm{C}$ & $99.50 \mathrm{~A}$ & $97.75 \mathrm{AB}$ & & $90.83 \mathrm{~B}$ & $96.50 \mathrm{~A}$ & $95.08 \mathrm{~A}$ & \\
\hline \multicolumn{9}{|c|}{ Straw Yield (t/ha) } \\
\hline $0 \% \mathrm{GR}$ & $3.88 \mathrm{c}$ & $4.87 \mathrm{~b}$ & $4.79 \mathrm{~b}$ & $4.51 \mathrm{~B}$ & $3.17 \mathrm{c}$ & $3.65 \mathrm{bc}$ & $3.66 \mathrm{bc}$ & $3.49 \mathrm{~B}$ \\
\hline $50 \%$ GR & $4.79 \mathrm{~b}$ & $4.98 \mathrm{ab}$ & $4.89 \mathrm{ab}$ & $4.89 \mathrm{AB}$ & $3.24 \mathrm{c}$ & $3.97 \mathrm{ab}$ & $3.92 \mathrm{ab}$ & $3.71 \mathrm{AB}$ \\
\hline $75 \%$ GR & $5.13 \mathrm{a}$ & $5.28 \mathrm{a}$ & $5.22 \mathrm{a}$ & $5.21 \mathrm{~A}$ & $3.81 \mathrm{~b}$ & $4.24 \mathrm{a}$ & $4.21 \mathrm{a}$ & $3.90 \mathrm{~A}$ \\
\hline $100 \%$ GR & $5.18 \mathrm{a}$ & $5.29 \mathrm{a}$ & $5.24 \mathrm{a}$ & $5.24 \mathrm{~A}$ & $3.78 \mathrm{~b}$ & $4.25 \mathrm{a}$ & $4.26 \mathrm{a}$ & $4.09 \mathrm{~A}$ \\
\hline Means & $4.75 \mathrm{~B}$ & $5.11 \mathrm{~A}$ & $5.04 \mathrm{~A}$ & & $3.68 \mathrm{~B}$ & $4.03 \mathrm{~A}$ & $4.01 \mathrm{~A}$ & \\
\hline \multicolumn{9}{|c|}{ Paddy yield (t/ha) } \\
\hline $0 \% \mathrm{GR}$ & $1.82 \mathrm{e}$ & $2.03 \mathrm{~d}$ & $1.98 \mathrm{de}$ & $1.94 \mathrm{C}$ & $1.69 \mathrm{~d}$ & $1.83 \mathrm{~b}$ & $1.75 \mathrm{c}$ & $1.76 \mathrm{~B}$ \\
\hline $50 \%$ GR & $2.13 \mathrm{~d}$ & $2.32 \mathrm{abc}$ & $2.31 \mathrm{abc}$ & $2.25 \mathrm{~B}$ & $1.90 \mathrm{~d}$ & $2.08 \mathrm{ab}$ & $1.97 \mathrm{ab}$ & $1.98 \mathrm{~B}$ \\
\hline $75 \%$ GR & $2.16 \mathrm{~cd}$ & 2. $49 \mathrm{ab}$ & $2.46 \mathrm{ab}$ & $2.36 \mathrm{AB}$ & $1.92 \mathrm{c}$ & $2.14 \mathrm{a}$ & $2.07 \mathrm{a}$ & $2.04 \mathrm{~A}$ \\
\hline $100 \%$ GR & $2.27 \mathrm{c}$ & 2. $48 \mathrm{ab}$ & $2.47 \mathrm{ab}$ & $2.41 \mathrm{~A}$ & $1.94 \mathrm{c}$ & $2.16 \mathrm{a}$ & $2.09 \mathrm{a}$ & $2.06 \mathrm{~A}$ \\
\hline Means & $2.10 \mathrm{~B}$ & $2.33 \mathrm{~A}$ & $2.31 \mathrm{~A}$ & & $1.86 \mathrm{C}$ & $2.05 \mathrm{~A}$ & $1.97 \mathrm{~B}$ & \\
\hline
\end{tabular}

Means bearing same letter(s) in each column are statistically similar at $\mathrm{p}=0.05$; $\mathrm{GM}=$ green Manuring; $\mathrm{CR}=$ crop residues; GR = gypsum requirement

crops. Although GM and CR significantly enhanced the number of productive tillers even at lower level $(50 \%)$ GR, which was statistically at par with higher level $(100 \%)$ of GR. The least number of productive tillers under GM and CR application were recorded at $0 \%$ GR which was again statistically equal to $100 \%$ GR without GM and CR incorporation.

The increased tillering in both DSR and TR with incorporation of GM and CR might be due to the enhanced bio-availability of nutrients, especially of $\mathrm{P}$ in the rooting medium as the decomposition of organic matter produces an acidic media that makes the phosphorus available to the plants due to lowering of $\mathrm{pH}$ in rhizosphere and providing a favorable environment. These results are supported by the findings of Sarir et al. (1992) and Mahmood and Ali (2015), who reported that the tillering is directly proportional to phosphorus availability while deficiency of phosphorus causes reduction in number of tillers and ultimately reduced yield. The findings of Sarwar (2005) also argued in favor of these results that the crop yield and yield parameters like plant height, number of productive tillers and 1000-grain weight of rice and wheat increased significantly with the application of different organic materials.

Paddy and straw yields. In terms of paddy yield, the data depicted in Table 2 emphasize the significance of GM and CR on crop yield at all applied levels of gypsum. The results revealed that the paddy yield was increased with the increasing GR applied without GM or CR incorporation. The maximum yield was attained at 100\% GR level in both DSR and TPR (2.27 and $1.94 \mathrm{t} / \mathrm{ha}$, respectively) followed by $75 \%$ GR (2.16 and $1.92 \mathrm{t} / \mathrm{ha}$, respectively) and 50\% GR (2.13 and $1.90 \mathrm{t} / \mathrm{ha}$, respectively). Overall DSR out yielded TPR in all treatments even at control ( $0 \%$ GR). Paddy yield was further improved with the incorporation of GM and CR to almost all GR levels and was statistically at par with each other for both DSR and TPR. A similar trend was found in straw yield for different sowing methods advocating the fact that GM and CR incorporation significantly influenced the straw yield at almost all 
GR levels. However, GM with 100\% GR level showed the best results in DSR with a straw yield of $5.29 \mathrm{t} / \mathrm{ha}$, followed by $75 \%$ and $50 \%$ GR (5.28 and $4.24 \mathrm{t} / \mathrm{ha}$, respectively). While straw yield for TPR was observed in GM with $100 \%$ GR level, that was recorded as 4.25 $\mathrm{t} / \mathrm{ha}$, followed by $75 \%$ and $50 \%$ (4.24 and $3.97 \mathrm{t} / \mathrm{ha}$, respectively). The effect of CR with GR levels was also found significant, however, CR with $100 \%$ GR produced the maximum straw yield in both DSR and TPR (5.24 and $4.26 \mathrm{t} / \mathrm{ha}$, respectively) followed by $75 \%$ and $50 \%$ GR levels.

It could be assessed from the results that the application of GM and CR increased the number of productive tillers by making the phosphorus availability and adding up the soil with certain essential nutrients upon decomposition that are necessary for plant growth and ultimately increasing the paddy yield. The results regarding paddy yield are augmented by the fact that the decomposition of applied organic materials resulted in reduction of soil $\mathrm{pH}$, because various acids (amino acid, glycine, cysteine and humic acid) or acid forming compounds were released during decomposition from the added organic materials (Brady and Weil, 2005). This reduction in soil $\mathrm{pH}$ increased the availability of nutrients of alkaline soil that were used by the plants. The enhanced uptake of $\mathrm{K}$ by rice improved the metabolic activities in the plants. Because of summation all above processes, various yield components (maximum plant height and number of productive tillers/plant) of rice were positively affected (Table 2) and ultimately these components contributed towards increased paddy yields of DSR and TPR. Parmer and Sharma (2002) also claimed increased yields of rice as well as wheat crops with the use of different organic materials alone or in combination with mineral fertilizer.

Soil rehabilitation and fertility restoration. The data in Table 3 translate that there is significant reduction in SAR and ECe values owing to GM and CR incorporation even with $50 \%$ GR of salt-affected soil under DSR as well as TPR. The soil ECe fell to 3.43 and $3.38 \mathrm{dS} / \mathrm{m}$ under DSR from $6.78 \mathrm{dS} / \mathrm{m}$ due to continuous GM and CR incorporation, respectively. Similarly, under TPR, GM and CR decreased the ECe to 3.36 and $3.33 \mathrm{dS} / \mathrm{m}$, after the harvest of last crop. The highest value of SAR $21.41(\mathrm{mmolc} / \mathrm{L})^{1 / 2}$ was recorded from control treatments where no amendment was applied whereas it was substantially declined to permissible limit i.e., 13.12 and $13.17(\mathrm{mmolc} / \mathrm{L})^{1 / 2}$ under GM and CR incorporation along with $100 \%$ GR. This was most probably due to mineralization and complete decomposition of GM and CR resulting in enhanced removal of $\mathrm{Na}^{+}$ions and addition of $\mathrm{Ca}^{2+}$ in

Table 3. Impact of green manuring and crop residue incorporation along with gypsum on rehabilitation of saltaffected soils after the harvest of second year rice crop (Average of three replications)

\begin{tabular}{|c|c|c|c|c|c|c|c|c|}
\hline \multirow[t]{2}{*}{ Treatments } & \multicolumn{4}{|c|}{ Direct seeded rice } & \multicolumn{4}{|c|}{ Transplanted rice } \\
\hline & Control & GM & $\mathrm{CR}$ & Mean & Control & GM & CR & Mean \\
\hline \multicolumn{9}{|l|}{$\mathrm{EC}(\mathrm{dS} / \mathrm{m})$} \\
\hline $0 \%$ GR & $6.79 \mathrm{a}$ & $3.64 \mathrm{~d}$ & $3.61 \mathrm{~d}$ & $4.68 \mathrm{~A}$ & $5.97 \mathrm{a}$ & $3.52 \mathrm{~cd}$ & $3.58 \mathrm{~cd}$ & $4.36 \mathrm{~A}$ \\
\hline $50 \% \mathrm{GR}$ & $5.84 \mathrm{~b}$ & $3.47 \mathrm{de}$ & $3.49 \mathrm{de}$ & $4.27 \mathrm{AB}$ & $5.33 \mathrm{ab}$ & $3.36 \mathrm{de}$ & 3.44 cde & $4.04 \mathrm{~B}$ \\
\hline $75 \%$ GR & $4.67 \mathrm{c}$ & $3.31 \mathrm{e}$ & $3.22 \mathrm{ef}$ & $3.73 \mathrm{~B}$ & $4.19 \mathrm{bc}$ & $3.29 \mathrm{de}$ & $3.16 \mathrm{de}$ & $3.55 \mathrm{C}$ \\
\hline $100 \%$ GR & $4.61 \mathrm{c}$ & $3.29 \mathrm{e}$ & $3.21 \mathrm{ef}$ & $3.72 \mathrm{~B}$ & $4.11 \mathrm{bc}$ & $3.26 \mathrm{de}$ & $3.14 \mathrm{de}$ & $3.53 \mathrm{C}$ \\
\hline Mean & $5.48 \mathrm{~A}$ & $3.43 \mathrm{~B}$ & $3.38 \mathrm{~B}$ & & $4.90 \mathrm{~A}$ & $3.36 \mathrm{~B}$ & $3.33 \mathrm{~B}$ & \\
\hline \multicolumn{9}{|l|}{ SAR } \\
\hline $0 \%$ GR & $21.41 \mathrm{a}$ & $16.48 \mathrm{~b}$ & $16.72 \mathrm{~b}$ & $18.20 \mathrm{~A}$ & $20.98 \mathrm{a}$ & $15.88 \mathrm{~cd}$ & $15.69 \mathrm{~cd}$ & $17.52 \mathrm{~A}$ \\
\hline $50 \% \mathrm{GR}$ & $20.86 \mathrm{a}$ & $13.23 \mathrm{~cd}$ & $13.31 \mathrm{~cd}$ & $15.80 \mathrm{~B}$ & $19.31 \mathrm{ab}$ & $13.47 \mathrm{e}$ & $13.42 \mathrm{e}$ & $15.40 \mathrm{~B}$ \\
\hline $75 \%$ GR & $17.79 \mathrm{~b}$ & $13.16 \mathrm{~cd}$ & $13.22 \mathrm{~cd}$ & $14.72 \mathrm{BC}$ & $17.28 \mathrm{c}$ & $12.43 \mathrm{ef}$ & $13.34 \mathrm{e}$ & $14.35 \mathrm{AB}$ \\
\hline $100 \%$ GR & $14.26 \mathrm{c}$ & $13.12 \mathrm{~cd}$ & $13.17 \mathrm{~cd}$ & $13.52 \mathrm{C}$ & $14.17 \mathrm{~d}$ & $12.40 \mathrm{ef}$ & $13.28 \mathrm{e}$ & $13.28 \mathrm{BC}$ \\
\hline Means & $18.58 \mathrm{~A}$ & $14.00 \mathrm{~B}$ & $14.11 \mathrm{~B}$ & & $17.94 \mathrm{~A}$ & $13.55 \mathrm{~B}$ & $13.93 \mathrm{~B}$ & OM $(\%)$ \\
\hline \multicolumn{9}{|l|}{$\mathrm{OM}(\%)$} \\
\hline $0 \%$ GR & $0.32 \mathrm{c}$ & $0.46 \mathrm{~b}$ & $0.46 \mathrm{~b}$ & $0.41 \mathrm{AB}$ & $0.33 \mathrm{~cd}$ & $0.49 \mathrm{ab}$ & $0.48 \mathrm{ab}$ & $0.43 \mathrm{~B}$ \\
\hline $50 \% \mathrm{GR}$ & $0.35 \mathrm{c}$ & $0.51 \mathrm{a}$ & $0.52 \mathrm{a}$ & $0.46 \mathrm{~A}$ & $0.36 \mathrm{c}$ & $0.52 \mathrm{a}$ & $0.51 \mathrm{a}$ & $0.46 \mathrm{AB}$ \\
\hline $75 \%$ GR & $0.36 \mathrm{c}$ & $0.54 \mathrm{a}$ & $0.53 \mathrm{a}$ & $0.48 \mathrm{~A}$ & $0.37 \mathrm{c}$ & $0.54 \mathrm{a}$ & $0.52 \mathrm{a}$ & $0.48 \mathrm{~A}$ \\
\hline $100 \%$ GR & $0.38 \mathrm{c}$ & $0.55 \mathrm{a}$ & $0.55 \mathrm{a}$ & $0.49 \mathrm{~A}$ & $0.39 \mathrm{c}$ & $0.56 \mathrm{a}$ & $0.55 \mathrm{a}$ & $0.50 \mathrm{~A}$ \\
\hline Mean & $0.35 \mathrm{~B}$ & $0.52 \mathrm{~A}$ & $0.52 \mathrm{~A}$ & & $0.33 \mathrm{~B}$ & $0.53 \mathrm{~A}$ & $0.52 \mathrm{~A}$ & \\
\hline
\end{tabular}

Means bearing same letter(s) in each column are statistically similar at $\mathrm{p}=0.05$. $\mathrm{GM}=$ green manuring; $\mathrm{CR}=$ crop residues; $\mathrm{GR}=$ gypsum requirement; $\mathrm{EC}=$ electrical conductivity; $\mathrm{SAR}=$ sodium adsorption ratio; $\mathrm{OM}=$ organic matter. 
the rhizosphere. After second crop harvest, overall, there was a significant improvement (17 and $18 \%$ ) in soil organic matter (SOM) content due to GM and CR incorporation, respectively under both DSR and TPR as compared to control (without GM and CR). Although, the maximum SOM contents were recorded from the treatments where GM and CR were incorporated along with increased gypsum application (100\% GR) under both DSR and TPR crops, however, the lower rates (50 and $75 \%$ GR) of gypsum application also performed statistically equal to the $100 \%$ GR. The reason might be that GM and CR incorporation upon decaying modified the soil environment which improved SOM content through decomposition of added organic materials. This could be supported by the findings of Mahmood and Ali (2015); Mahmood et al. (2013); Ali et al. (2012); Shiva et al. (2012); Kharub et al. (2004); Yadvinder et al. (2004) and Qadir et al. (2003).

\section{Conclusion}

On an average of two-years data, the DSR grown under GM and CR incorporation along with gypsum application even at lower rate (50\% GR) performed statistically equal and produced comparable paddy yield as that of higher rates ( 75 and $100 \%$ GR) which was significantly better than that of $100 \%$ GR without GM or CR incorporation. Soil health (in terms of SOM improvement and decrease in ECe and SAR) was also improved owing to GM and CR incorporation. This practice should be continued for at least 3-5 years for amelioration of saline-sodic and/or sodic soils.

Conflict of Interest. The authors declare no conflict of interest

\section{References}

Ali, A., Arshadullah, M., Hyder, S.I., Mahmood, I.A., Zaman, B. 2012. Rice productivity and soil health as affected by wheat residue incorporation along with nitrogen starter dose under salt-affected soil. Pakistan Journal of Agricultural Research, 25: 257-265.

Brady, N.C., Weil, R.R. 2005. The Nature and Properties of Soil, $13^{\text {th }}$ edition, Macmillan Publishing Co., New York, USA.

Byous, E.W., Williuams, J.E., Jonesa, G.E., Horwath, W.R., Kessel, C. 2004. Nutrient requirements of rice with alternative straw management. Better Crops, 36: 6-11.
Danga, B.O., Wakindiki, I.I.C. 2009. Effect of placement of straw mulch on soil conservation, nutrient accumulation and wheat yield in a humid Kenyan high land. Journal of Tropic Agriculture, 47: 3036.

Eagle, A.J., Bird, J.A., Horwaath, W.R., Linquist, B.A., Brouder, S.M., Hill, J.E., Kessel, C.V. 2000. Rice yield and nitrogen utilization efficiency under alternative straw management practices. Agronomy Journal, 92: 1096-1103.

Ghafoor, A., Murtaza, G., Ahmad, B., Boers, T.M. 2008. Evaluation of amelioration treatments and economic aspects of using saline-sodic water for rice and wheat production on salt-affected soils under arid land conditions. Irrigation and Drainage, 57: 424434.

Gomez, K.A., Gomez, A.A. 1984. Statistical Procedure for Agricultural Research, $2^{\text {nd }}$ edition, John Wiley and Sons., New York, USA.

GOP, 2016. Economic Survey 2015-2016. Finance Division, Economic Advisory Wing, Government of Pakistan, Islamabad, Pakistan.

Kharub, A.S., Sharma, R.K., Mongia, A.D., Chhokar, R.S., Tripathi, S.C., Sharma, V.K. 2004. Effect of rice (Oryza sativa) straw removal, burning and incorporation on soil properties and crop productivity under rice-wheat (Triticum aestivum) system. Indian Journal of Agricultural Sciences, 74: 295-299.

Mahmood, I.A., Ali, A. 2015. Response of direct seeded rice and wheat crops to phosphorus application with crop residue incorporation in saline-sodic soil. International Journal of Agriculture \& Biology, 17: 1219-1224.

Mahmood, I.A., Ali, A., Aslam, M., Shahzad, A., Sultan, T., Hussain, F. 2013. Phosphorus availability in different salt-affected soils as influenced by crop residue incorporation. International Journal of Agriculture \& Biology, 15: 472-478.

Murtaza, G., Ghafoor, A., Owens, G., Qadir, M., Kahlon, U.Z. 2009. Environmental and economic benefits of saline-sodic soil reclamation using low-quality water and soil amendments in conjuction with a rice-wheat cropping system. Journal of Agronomy and Crop Sciences, 195: 124-136.

Parmer, D.K., Sharma, V. 2002. Studies on long-term application of fertilizers and manure on yield of maize-wheat rotation and soil properties under rainfed conditions in Western Himalayas. Journal of the Indian Society of Soil Science, 50: 311-312. 
Qadir, M., Steffens, D., Schubert, E. 2003. Sodium removal from a calcareous saline-sodic soil through leaching and plant uptake during phytoremediation. Land Degradation and Development, 14: 301-307.

Rhoades, J.D. 1982. Cation Exchange Capacity. In: Methods of Soil Analysis. Part 2. Chemical and Microbiological Properties. A.L. Page, (ed.), pp. 149-158. American Society of Agronomy, Madison, Wisconsin, USA.

Ryan, J., Estefan, G., Rashid, A. 2001. Soil and Plant Analysis Laboratory Manual, pp: 172. International Center for Agricultural Research in the Dry Areas (ICARDA), Aleppo, Syria.

Sarir, M.S., Khalil, M.H., Shah, M., Nisar, M. 1992. The utilization efficiency of different phosphatic fertilizer reinforced with FYM on wheat production. Sarhad Journal of Agriculture, 8: 379-384.

Sarwar, G. 2005. Use of compost for crop production in Pakistan. Ökologie und Umweltsicherung. 26/2005. Universität Kassel, Fachgebiet Landschaftsökologie und Naturschutz, Witzenhausen, Germany.
Shiva, D., Vyas, A.K., Shivay, Y.S., Kumar, D., Kumar, A. 2012. Yield of wheat and residual soil fertility under organic and inorganic fertilization. In: Proceeding of National Seminar on Indian Agriculture: Preparedness for Climate Change, March 24-25, 2012, New Delhi. D. Shiva, S. Barthakur, K. Prajapati, K. Annapurna, T. Satyavathi, A.K. Vyas, (eds.), pp 139-140. Indian Society of Agricultural Sciences, Division of Agronomy, IARI, New Delhi, India.

Tuna, A.L., Kaya, C., Ashraf, M., Altunlu, H., Yokas, I., Yagmur, B. 2007. The effects of calcium sulphate on growth, membrane stability and nutrient uptake of tomato plants grown under salt stress. Environmental and Experimental Botany, 59: 173178.

Yadvinder, S., Bijay, S., Ladha, J.K., Khind, C.S., Khera, T.S., Bueno, C.S. 2004. Effects of residue decomposition on productivity and soil fertility in rice-wheat rotation. Soil Science Society of American Journal, 68: 854-864. 